\title{
Effect of Rosuvastatin on Arginase Enzyme Activity and Polyamine Production in Experimental Breast Cancer
}

\author{
Hakan Erbaş, Oğuz Bal, Erol Çakır \\ Department of Medical Biochemistry, Trakya University Faculty of Medicine, Edirne, Turkey
}

Background: Breast cancer is the most common malignant tumour of women around the world. As a key enzyme of the urea cycle, arginase leads to the formation of urea and ornithine from L-arginine. In the patients with several different cancers, arginase has been found to be higher and reported to be a useful biological marker.

Aims: The aim of this study was to investigate the effect of rosuvastatin on serum and cancer tissue arginase enzyme activity, and ornithine and polyamine (putrescine, spermidine, spermine) levels.

Study Design: Animal experiment.

Methods: In this study, 50 male Balb/c mice were used. Erchlich acid tumour cells were injected into the subcutaneous part of their left foot. The mice were divided into five groups: healthy control group, healthy treatment, tumour control, treatment 1 and treatment 2 . Then, $1 \mathrm{mg} / \mathrm{kg}$ and $20 \mathrm{mg} / \mathrm{kg}$ doses of rosuvastatin were given intraperitoneally. Serum and tissue arginase enzyme activities and tissue ornithine levels were de- termined spectrophotometrically. HPLC measurement of polyamines were applied.

Results: Increased serum arginase activity and polyamine levels were significantly decreased with rosuvastatin treatment. In the tumour tissue, arginase activity and ornithine levels were significantly decreased in treatment groups compared to the tumour group. Tissue polyamine levels also decreased with rosuvastatin treatment.

Conclusion: We suggest that rosuvastatin may have some protective effects on breast cancer development as it inhibits arginase enzyme activity and ornithine levels, precursors of polyamines, and also polyamine levels. This protective effect may be through the induction of nitric oxide (NO) production via nitric oxide synthase (NOS). As a promising anticancer agent, the net effects of rosuvastatin in this mechanism should be supported with more advanced studies and new parameters.

Keywords: Arginase, breast cancer, ornithine, polyamines, rosuvastatin
Breast cancer is still the commonest type of cancer in women. It accounts for about $20 \%$ of all cancer-related mortality. Therefore, great medical and scientific efforts are continually invested into understanding the disease's pathology and finding new methods for its early diagnosis, prevention and treatment.

In cells, L-arginine is embraced in protein synthesis. Arginine is also used by arginase, arginine decarboxylase, nitric oxide synthases (NOSs) and glycine transaminase. Arginase is a crucial enzyme that is chargeable for nitrogen metabolism. Arginine is its main substrate; from this, urea and L-ornithine are formed (1). There are two types of arginase: Arginase I is cytosolic and mostly found in the liver; it is considered to be primarily liable for the detoxification of ammonia. The other isoenzyme, arginase II, is engaged in ornithine creation. Ornithine is the precursor of some products which take place in cell growth: glutamate, proline and polyamines (spermine,

This study was presented as a poster at the congress of IFCC WorldLab, 22-26 June 2014, İstanbul, Turkey.

Address for Correspondence: Dr. Hakan Erbaş, Department of Medical Biochemistry, Trakya University Faculty of Medicine, Edirne, Turkey Phone: +90 5519340420 e-mail: herbas@trakya.edu.tr

Received: 11.06.2014 Accepted: 08.10.2014 • DOI: 10.5152/balkanmedj.2015.15611

Available at www.balkanmedicaljournal.org 
spermidine and putrescine) (2). As polyamines are crucial for cell proliferation, it is probable that the elevated level of ornithine, due to increased arginase activity, could be lead to the development of cancer (3).

Nitric oxide (NO) production is dependent on NOSs which are the enzymes that synthesis the oxidation of arginine to NO and citrulline. Three different types of NOS are available: neuronal (nNOS or NOS1), inducible (iNOS or NOS2) and endothelial (eNOS or NOS3). eNOS and nNOS are believed to be constitutive (cNOS) (4). NO has several aspects in cells and its action may vary depending on its level (5). Studies have proposed that in cancer growth, NO may have an important action as a preventative and therapeutic agent. The use of NO donors as cancer therapeutics had been shown as a new venue that has not been appreciated in the past, because NO was primarily used for the treatment of blood vessel-related disorders and in other non-cancer conditions. In cancer cells, the indication of NO-mediated cytotoxicity through its antiproliferative and chemo-sensitising behaviour supported the idea of their usage in cancer therapy (5).

Many different studies conducted on various types of cancer arginase levels in the serum and tissues examined have associated arginase enzyme activity with cancer. Some researchers even emphasised of arginase enzyme activity as an important determinant even in patients with breast cancer (6).

Studies have shown that polyamines are the polycationic compounds necessary for growth and division in all cells (7). They are aliphatic molecules that are responsible in various fields such as cell division, protein-DNA interactions, cell differentiation, embryonic development, immunological interactions, signal transduction, apoptosis, DNA and RNA conformational change tasks and cancer (8). Although the increase in level of the polyamine concentration known to be associated with cell proliferation, in recent studies, these molecules have been shown to play an important role in both normal and cancer growth (9).

As a synthetic molecule, rosuvastatin was chosen; this is a 3-hydroxy-3-methyl-glutaryl coenzyme A (HMG CoA) reductase inhibitor (10). Rosuvastatin selectively, reversibly and competitively inhibits the enzyme which catalyses the formation of mevalonic acid from HMG-CoA as a rate-limiting step in cholesterol synthesis (10).

As with other statins, rosuvastatin has some other effects besides the inhibition of HMG CoA reductase. These are the improvements in endothelial function, anti-inflammatory, antithrombotic and antioxidant effects (10). It has been emphasised that rosuvastatin decreased the oxidative stress by increasing antioxidant capacity (11). It has also been suggested that it reduced the free radical damage to the DNA through some antioxidant mechanisms such as the down-regulation of NADPH oxidase and increased expression of the enzymes which contribute to glutathione metabolism (12). Statins are emphasised to regulate the endothelial and cardiovascular functions by increasing the formation of $\mathrm{NO}$ (13).

In this study, we aimed to investigate the possible positive effects of rosuvastatin, a statin for which the antioxidant and anti-carcinogenic effects have been shown in previous studies, on breast cancer development. For this purpose, we determined the breast cancer serum and tissues arginase enzyme activities, as well as ornithine and polyamine levels in mice.

\section{MATERIALS AND METHODS}

\section{Animals and tumour}

This study was performed in the Experimental Animal Breeding and Research Unit of the University upon approval by the local animal ethics committee (2011.09.05/09). Fifty adult male inbred BALB/c mice ( 8 weeks old) were used in the experiment. The weight of the animals was $30 \pm 3 \mathrm{~g}$. Ehrlich ascites tumour cells which were derived from a spontaneous murine mammary adenocarcinoma were used obtaining the breast carcinoma.

\section{Experimental design}

In the eighth week, five groups were formed. The first group was healthy controls. The other groups were breast cancer. To induce the formation of tumours, subcutaneous inoculation of Ehrlich ascites cells into the mice's left footpath was performed. Tumour development was assessed after 7 days by measuring their footpad thickness. On the 7th day, treatments were started. Group 2 was formed with healthy animals (healthy control+treatment, $1 \mathrm{mg} / \mathrm{kg} /$ day). Group 3 was a tumour control group and received saline solution (tumour control). Group 4 received $1 \mathrm{mg} / \mathrm{kg}$ /day rosuvastatin (tumour+treatment 1). Rosuvastatin was a gift from Sanovel (İstanbul, Turkey). Group 5 received $20 \mathrm{mg} / \mathrm{kg}$ /day rosuvastatin (tumour+treatment 2) for 15 days intraperitoneally (ip). At the end of the treatment period, the animals were sacrificed under anaesthetic. Serum and tissue samples were taken and stored at $-80^{\circ} \mathrm{C}$.

\section{Determination of Argininase enzyme activity in serum and tissue}

Serum arginase enzyme activity was determined spectrophotometrically according to Munder (14).

Breast cancer tissue arginase activity was measured spectrophotometrically according to the tiosemicarbazide diacetylmonoxime urea (TDMU) method (15).

Breast tissue ornithine levels were determined spectrophotometrically with the Chinard Method (15).

\section{HPLC measurement of polyamines}

Before starting to work, serum samples were removed from $-80^{\circ} \mathrm{C}$ and dissolved at room temperature. For the tissue homogeni- 
TABLE 1. Serum and tissue arginase enzyme activities, putrescine, spermidine and spermine levels in groups (mean \pm SEM). "Serum comparisons between group 1 and group $3,{ }^{\S}$ Serum comparisons between group 3 and group $4,{ }^{8}$ Serum comparisons between group 3 and group 5 , ${ }^{\lambda}$ Tissue comparisons between group 3 and group $4,{ }^{\phi}$ Tissue comparisons between group 3 and group $5,{ }^{*}$ Tissue comparisons between group 4 and group $5,{ }^{*} \mathrm{p}<0.05,{ }^{* *} \mathrm{p}<0.01,{ }^{* * *} \mathrm{p}<0.001$

\begin{tabular}{|c|c|c|c|c|c|c|}
\hline & & Cont. & Cont + treat & Tumour & Tumour+treat 1 & Tumour+treat 2 \\
\hline \multirow{4}{*}{ 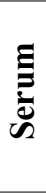 } & Arginase (U/L) & $2.89 \pm 0.15$ & $2.84 \pm 0.20$ & $3.71 \pm 0.13^{\# * *}$ & $2.94 \pm 0.13^{\S * * *}$ & $2.59 \pm 0.13^{\varepsilon * * *}$ \\
\hline & Putresine (nmol/mL) & $225.4 \pm 83.6$ & $165.7 \pm 72.9$ & $1070 \pm 251^{\# *}$ & $16.45 \pm 9.34 \$ * * *$ & $3.62 \pm 0.99^{\varepsilon * * *}$ \\
\hline & Spermidine $(\mathrm{nmol} / \mathrm{mL})$ & $32.66 \pm 8.63$ & $37.22 \pm 12.46$ & $409 \pm 217^{\# *}$ & $3.21 \pm 1.38^{\S * * *}$ & $2.92 \pm 0.93^{\varepsilon * * *}$ \\
\hline & Spermine $(\mathrm{nmol} / \mathrm{mL})$ & $30.71 \pm 6.06$ & $31.55 \pm 7.56$ & $355.6 \pm 187^{\# * * *}$ & $10.44 \pm 4.93^{\S * * *}$ & $4.07 \pm 1.34^{\varepsilon * * *}$ \\
\hline & & Tumour & & Tumour+treat 1 & & Tumour+treat 2 \\
\hline \multirow{5}{*}{$\underset{\mathscr{V}}{\mathscr{V}}$} & Arginase (U/mg pr.) & $39.4 \pm 3.98$ & & $21.9 \pm 2.74^{\lambda * *}$ & & $20.7 \pm 2.75^{\phi * *}$ \\
\hline & Ornithine (nmol/mg pr.) & $72 \pm 10$ & & $45 \pm 3^{\lambda *}$ & & $39 \pm 2^{\phi * * *}$ \\
\hline & Putresine (nmol/mg pr.) & $7.51 \pm 1.45$ & & $4.51 \pm 1.27$ & & $3.26 \pm 0.89^{\phi * *}$ \\
\hline & Spermidine (nmol/mg pr.) & $40.6 \pm 9.42$ & & $30.0 \pm 10.4$ & & $2.15 \pm 0.15^{\phi * * *, \psi * * *}$ \\
\hline & Spermine (nmol/mg pr.) & $22.5 \pm 3.51$ & & $10.41 \pm 3.05$ & & $1.31 \pm 0.16$ \\
\hline
\end{tabular}

sation, phosphate buffer was used. Samples were homogenised with $0.05 \mathrm{M}$ phosphate buffer (5 times the weight, $\mathrm{pH}: 7.2$ ).

Here, $167 \mu \mathrm{L}$ of the sample was taken into the test tubes and $100 \mu \mathrm{L}$ of $10 \%$ trichloroacetic acid was added. Then, the samples were centrifuged for 10 minutes at $3000 \mathrm{~g}$ and the ultrafiltrate was obtained. For $200 \mu \mathrm{L}$ of sample ultrafiltrate, $25 \mu \mathrm{L}$ hexamethylenediamine, $25 \mu \mathrm{L}$ saturated sodium carbonate and $50 \mu \mathrm{L}$ dansyl chloride were added and vortexed. The mixture was kept at $50^{\circ} \mathrm{C}$ for 30 minutes in a water bath and subsequently centrifuged for 5 minutes at $4000 \mathrm{~g}$ and applied to the HPLC system (16).

In this method, Waters Alliance 2690 separation module, Model 474 fluorescence detector and Waters Millennium 32 software were used. Chromatography was performed on a $\mu$ Bondapak C18 cartridge ( $4.6 \times 250 \mathrm{~mm}, 5 \mu \mathrm{M}$ particle size $)$ with a guard column $(3.9 \times 20 \mathrm{~mm})$ packed with the same stationary phase (Waters, Milford, MA, USA). The column temperature was $50^{\circ} \mathrm{C}$ and flow rate was $1 \mathrm{ml} / \mathrm{min}$. Fluorescence was measured at excitation and emission wavelengths of 370 and $506 \mathrm{~nm}$, respectively.

\section{Statistical analysis}

The statistical analyses were performed with the SPSS software version 19.0 (IBM, New York, USA). The results were reported as mean \pm standard error of mean. The data were first analysed with the Shapiro-Wilk's test and were found to be nonparametric. Differences between the control and treatment group arginase enzyme activities and ornithine and polyamine levels were evaluated by Kruskal-Wallis test and compared with the Mann-Whitney U test. P values below 0.05 were recognised to be statistically significant.

\section{RESULTS}

In this study, serum arginase enzyme activities and ornithine and polyamine levels and tissue arginase enzyme activity and ornithine and polyamine levels were determined. All of those parameters are shown in Table 1.

In serum samples, a statistically significant decrease in arginase activity, putrescine, spermidine and spermine levels was observed for the rosuvastatin treatment compared to the tumour group, which was also significantly higher than the healthy controls (Figure 1). This decreasing effect was parallel with the dose of the rosuvastatin.

In tumour tissue, there was still a significant decrease in arginase activity, ornithine, putrescine, spermidine and spermine levels in the rosuvastatin treatment compared to the tumour group (Figure 2). This reduction was more relevant with the dose of the treatment.

\section{DISCUSSION}

In this study, for the first time in the current literature, we investigated the effects of rosuvastatin on the arginase enzyme system and polyamines in the breast cancer model. We clearly demonstrated that rosuvastatin had some beneficial effects on cancer progress as it significantly reduced the arginase enzyme activity and polyamine formation in breast cancer.

Nitric oxide synthases (NOSs) and arginase can compete for their common substrate, L-arginine; this interaction between the two enzymes represents a potentially important factor in the regulation of NO production. Elevated arginase activity could limit NO synthesis by reducing L-arginine availability for NOS (17). It has been documented that arginase activity is 5 -fold greater than NOS activity and arginase was found to be present in the major pathway of L-arginine metabolism in nephritic glomeruli (18); likewise, it was suggested that while arginase activity increases, NOS activity decreases in the erythrocytes of the patients with chronic renal failure (19). It was also reported that for the mammalian arginase, the $\mathrm{Km}$ for 

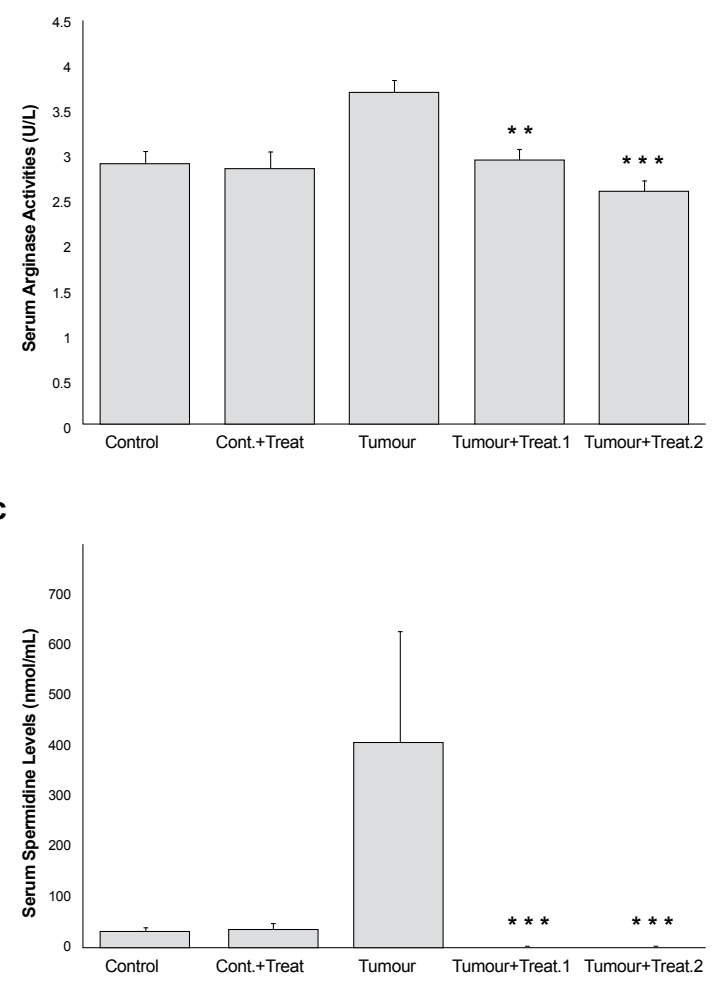

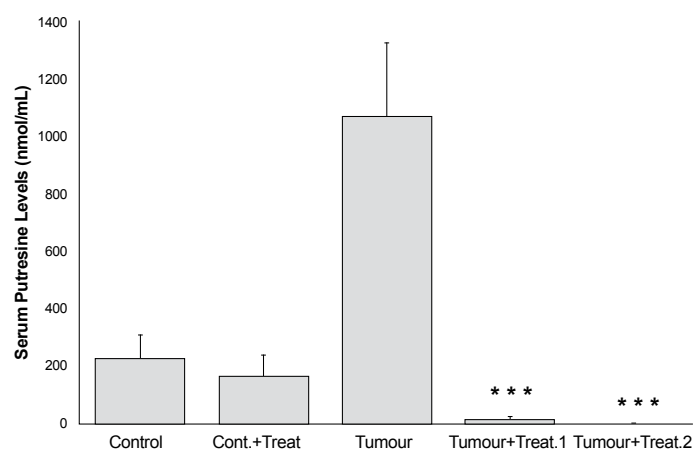

d

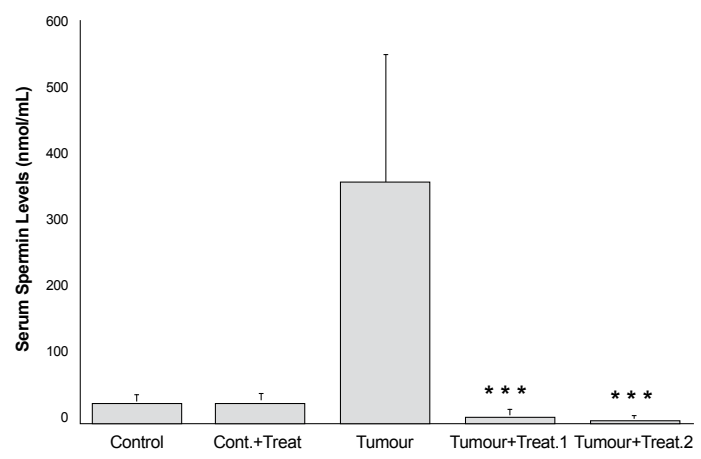

FIG. 1. a-d. Serum Arginase enzyme activities (a), Putrescine levels (b), Spermidine levels (c), Spermine levels in groups (d) (mean \pm SEM, ${ }^{*} p<0.05,{ }^{* *} p<0.01,{ }^{* * *} p<0.001$, comparisons between tumour control vs treatment groups)

L-arginine was 2-20 $\mathrm{mM}$ and 1-20 $\mathrm{mM}$ for the various NOS isoenzymes (20). However, at physiological $\mathrm{pH}$, the Vmax of each of the NOS enzymes was less than 1000-times that of arginase (21); therefore, it was concluded that both NOS and arginase could use arginine (22). Previously, we also showed that there was a negative relation between arginase enzyme activities and NO levels in breast cancer (15).

Nitric oxide is a pervasive molecule that employs many biological outcomes (5). The decisive effect of NO on tumour growth is complicated and remains largely unclear. While low levels of NO have been suggested to stimulate tumour cell proliferation and growth (23), and to increase the metastatic ability of tumour (24), high NO concentration may inhibit tumour growth $(25,26)$ and induce apoptosis in tumour cells (27). Studies have reported that the duration, expression level and timing of NO delivery, the microenvironment, the cell type and the genetic background might regulate NO sensitivity and the total effect of NO (28). NO can be used as a chemo-sensitising and immuno-sensitising agent (5), and thus, we believe its clinical application may help in the treatment of cancer.

Arginase has been found to be present in many non-hepatic tissues such as the mammary gland, intestine, kidney, brain and lungs (29). Extrahepatic arginase could be connected in the regulation of tissue repair and cell growth (1). Elevated arginase activity was found in a variety of established human breast cancer cells (6). Previous studies have demonstrated high levels of serum arginase activity in several different carcinomas including gastric, colorectal, large bowel, prostate, lungs and breast cancers, suggesting that this enzyme might serve as a useful biomarker in cancer and cancer progression (6). L-ornithine could be converted to proline and glutamate by ornithine aminotransferase. In mammalian cells, ornithine is substrate for the formation of glutamate, proline and polyamines (30). Polyamines have also been indicated to play an important part in cellular proliferation and growth $(30,31)$. They have also been associated with carcinogenesis (9). The exact mechanism(s) for arginase activity in cancer tissues are unknown. On the other hand, one possible mechanism would be dependent upon the elevated concentration of ornithine, a precursor of polyamines, and might result from an increase in extrahepatic arginase. Increased tissue arginase enzyme activity and ornithine levels together appear to enlarge polyamine formation, which could lead to cancer development.

Supporting this theory, in our study, we have demonstrated that serum arginase activity and polyamine levels increased in 
a

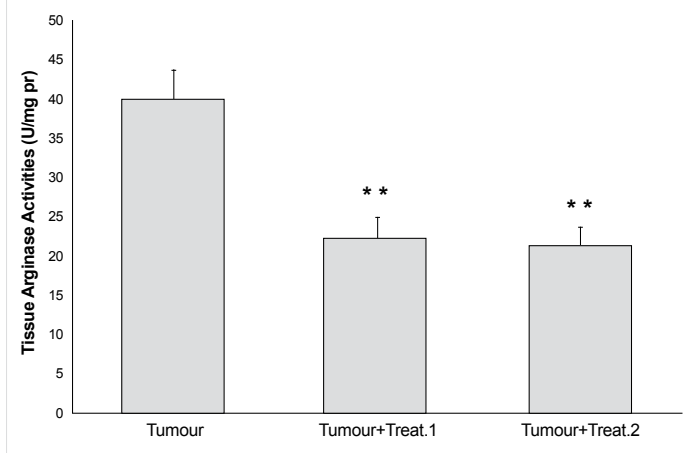

C

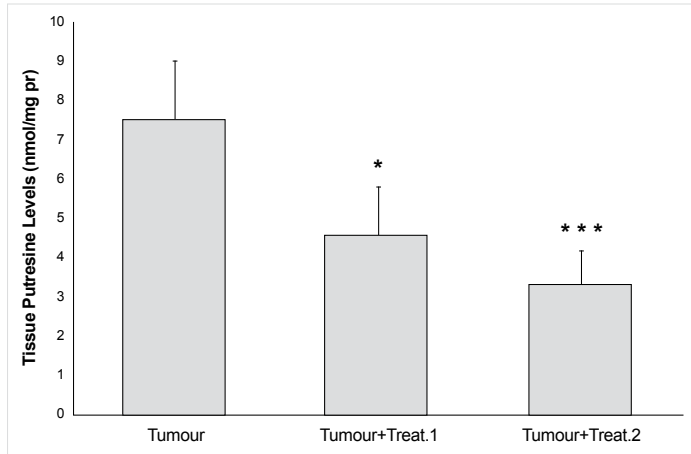

b

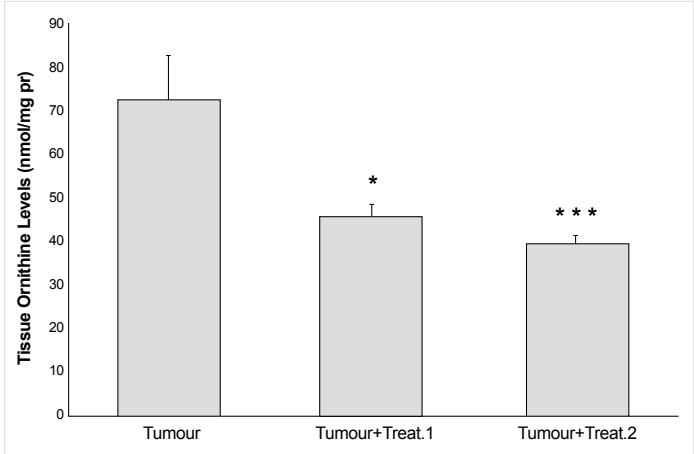

d

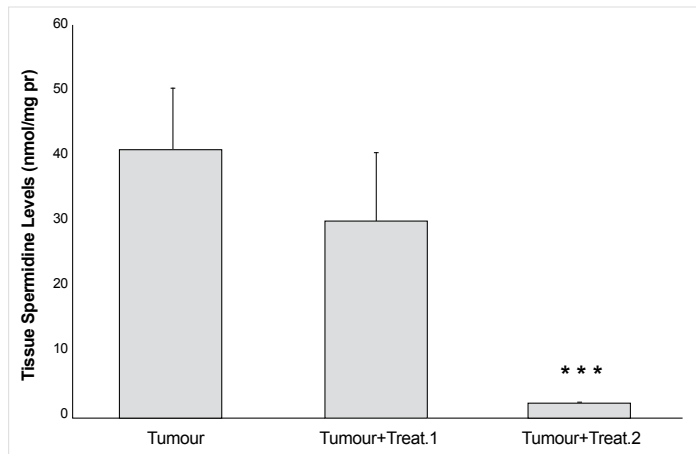

e

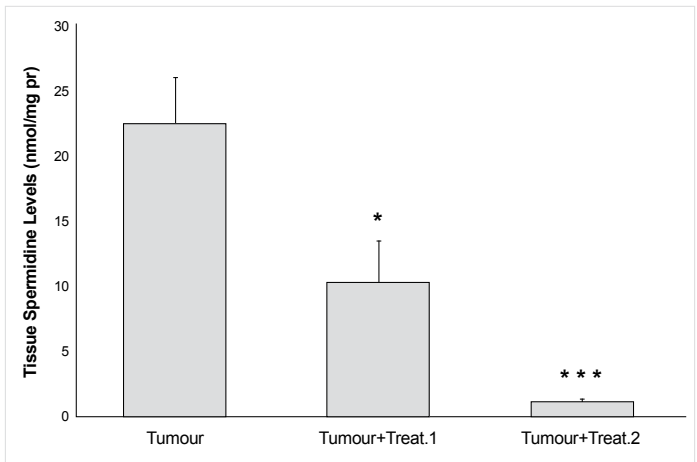

FIG. 2. a-e. Tissue Arginase enzyme activities (a), Ornithine levels (b), Putrescine levels (c), Spermidine levels (d), Spermine levels in groups (e) (mean \pm SEM, ${ }^{*} p<0.05,{ }^{* *} p<0.01,{ }^{* * *} p<0.001$, comparisons between tumour control vs treatment groups)

breast cancer and that rosuvastatin treatment significantly reduced these markers. Moreover, in tumour tissue, we had a similar action of reduction in the concentrations of cancer molecules, including ornithine. This reduction has been more relevant with the increased concentration of rosuvastatin.

It has been shown that statins inhibit cancer cell proliferation by stopping the cell cycle in G1-S phase and inducing apoptosis (13). In a study of experimental pancreatic cancer, the administration of statins has been shown to prevent cancer cell growth (32). A colorectal cancer study showed that statins had a $47 \%$ decrease in the probability of cancer progression (33). In a recent study on hepatocellular cancer, it was also shown that the use of statins reduced the risk of hepatocellular cancer (34).

In cancer development, one of the possible protective mechanisms could be NO production. While the inhibition of arginase will lead to the lower production of ornithine and polyamines, at the same time it would stimulate the NOS action and therefore the formation of NO. In one study, researchers also strongly emphasised that the action of the statins in MCF7 breast cancer cells should be through the higher production of NO via increasing NOS expression (13). 
As we know, statins like rosuvastatin inhibit HMG CoA reductase; this inhibition also leads to a reduction in the usage of its coenzyme, NADPH, which will lead to the formation of a high concentration of NADPH. NADPH is also a coenzyme for NOS and stimulates NOS activation. At the end, this mechanism would result in an increased NO formation. In other words, the high level of NADPH could depress arginase enzyme activity and may activate the NOS production, therefore decreasing polyamine production in breast cancer.

In polyamine metabolism, the main enzyme group is polyamine oxidases. The action of these enzymes involves hydrogen peroxide production. Hydrogen peroxide is also an effective negative feedback regulator of the enzyme at high concentrations and inhibits the catabolism of polyamines via reducing enzyme activities (35). One of the enzymes in hydrogen peroxidase detoxification is glutathione reductase, which needs NADPH for regeneration. In the NADPH high environment, hydrogen peroxide production would be inhibited, which would lead to a reduction in polyamine levels through the increase in polyamine catabolism. Another possible mechanism behind the finding of decreased polyamine levels in this study may be hidden at this point.

As a conclusion, we may suggest that rosuvastatin may have some protective effects on breast cancer development as it inhibits arginase enzyme activity, ornithine levels, precursors of polyamines, and also polyamines, therefore inducing NO production via NOS. As a promising anticancer agent, the net effects of rosuvastatin in this mechanism should be supported with more advanced studies and new parameters.

Ethics Committee Approval: Ethics committee approval was received for this study from the ethics committee of Trakya University Animal Ethics Committee (2011.09.05/09).

\section{Informed Consent: N/A.}

Peer-review: Externally peer-reviewed.

Author contributions: Concept - H.E., O.B., E.Ç.; Design - H.E., O.B., E.Ç.; Supervision - H.E., E.Ç.; Resource - H.E., O.B.; Materials - H.E., O.B.; Data Collection\&/or Processing - O.B.; Analysis\&/ or Interpretation - H.E., O.B.; Literature Search - H.E., O.B.; Writing - H.E., O.B., E.Ç.; Critical Reviews - H.E., E.Ç.

Acknowledgements: We thank to Sanovel for supplying rosuvastatin as a gift.

Conflict of Interest: No conflict of interest was declared by the authors.

Financial Disclosure: The authors declared that this study has received financial support from Trakya University Research Project (TUBAP 2012/42).

\section{REFERENCES}

1. Jenkinson CP, Grody WW, Caderbaum SD. Comparative properities of arginases. Comp Biochem Physiol B Biochem Mol Biol 1996;114:107-32. [CrossRef]

2. Cederbaum SD, Yu H, Grody WW, Kern RM, Yoo P, Iyer RK. Arginases I and II: do their functions overlap? Mol Genet Metab 2004;81:S38-44. [CrossRef]

3. Porembska Z, Luboinski G, Chrzanowska A, Mielczarek M, Magnuska J, Baranczyk-Kuzma A. Arginase in patients with breast cancer. Clin Chim Acta 2003;328:105-11. [CrossRef]

4. Lowe DT. Nitric oxide dysfunction in the pathophysiology of preeclampsia. Nitric Oxide 2000;4:441-58. [CrossRef]

5. Bonavida B, Khineche S, Huerta-Yepez S, Garban H. Therapeutic potential of nitric oxide in cancer. Drug Resist Updat 2006;9:157-73. [CrossRef]

6. Singh R, Avliyakulov NK, Braga M, Haykinson MJ, Martinez L, Singh V, et al. Proteomic identification of mitochondrial targets of arginase in human breast cancer. PLoS One 2013;8:115. [CrossRef]

7. Thomas T, Thomas TJ. Polyamines in cell growth and cell death: molecular mechanisms and therapeutic applications. Cell Mol Life Sci 2001;58:244-58. [CrossRef]

8. Wallace HM, Fraser AV, Hughes A. A perspective of polyamine metabolism. Biochem J 2003;376:1-14. [CrossRef]

9. Park MH, Igarashi K. Polyamines and their metabolites as diagnostic markers of human diseases. Biomol Ther (Seoul) 2013;21:1-9. [CrossRef]

10. Luvai A, Mbagaya W, Hall AS, Barth JH. Rosuvastatin: a review of the pharmacology and clinical effectiveness in cardiovascular disease. Clin Med Insights Cardiol 2012;6:17-33.

11. Kim YS, Ahn Y, Hong MH, Kim KH, Park HW, Hong YJ, et al. Rosuvastatin suppresses the inflammatory responses through inhibition of c-Jun N-terminal kinase and Nuclear Factor-kappaB in endothelial cells. $J$ Cardiovasc Pharmacol 2007;49:376-83. [CrossRef]

12. Schupp N, Schmid U, Heidland A, Stopper H. Rosuvastatin protects against oxidative stress and DNA damage in vitro via upregulation of glutathione synthesis. Atherosclerosis 2008;199:278-87. [CrossRef]

13. Kotamraju S, Williams CL, Kalyanaraman B. Statin-induced breast cancer cell death: role of inducible nitric oxide and arginase-dependent pathways. Cancer Res 2007;67:7386-94. [CrossRef]

14. Munder M, Eichmann K, Moran JM, Centeno F, Soler G, Modolell M. Th1/Th2- regulated expression of arginase isoforms in murine macrophages and dendritic cells. J Immunol 1999;163:3771-7.

15. Erbas H, Aydogdu N, Usta U, Erten O. Protective role of carnitine in breast cancer via decreasing arginase activity and increasing nitric oxide. Cell Biol Int 2007;31:1414-9. [CrossRef]

16. Fu S, Xiao C, Zhao W, Yu X. Polyamines analysis by HPLC and their application as tumor markers. Frontiers Biosci (Elite Ed.) 2012;4:1795-801.

17. Ishii N, Ikenaga H, Carmines PK, Aoki Y, Ogawa Z, Saruta T, et al. High glucose augments arginase activity and nitric oxide production in the renal cortex. Metabolism 2004;53:868-74. [CrossRef] 
18. Jansen A, Lewin S, Cattell V, Cook HT. Arginase is a major pathway of L-arginine metabolism in nephritic glomeruli. Kidney Int 1992;42:1107-12. [CrossRef]

19. Durak I, Oztürk HS, Elgün S, Cimen MY, Yalçin S. Erythrocyte nitric oxide metabolism in patients with chronic renal failure. Clin Nephrol 2001;55:460-4.

20. Grody WW, Dizikes GJ, Cederbaum SD. Human arginase isozymes. Isozymes Curr Top Biol Med Res 1987;13:181-214.

21. Griffith OW, Stuehr DJ. Nitric oxide synthases. Properties and catalytic mechanism. Ann Rev Physiol 1995;57:707-36. [CrossRef]

22. Singh R, Pervin S, Karimi A, Cederbaum S, Chaudhuri G. Arginase activity in human breast cancer cell lines. N(omega)hydroxy-L-arginine selectively inhibits cell proliferation and induces apoptosis in MDA-MB-468 cells. Cancer Res 2000;60:3305-12.

23. Jenkins DC, Charles IG, Thomsen LL, Moss DW, Holmes LS, Baylis SA, et al. Roles of nitric oxide in tumor growth. Proc Natl Acad Sci USA 1995;92:4392-6. [CrossRef]

24. Edwards P, Cendan JC, Topping DB, Moldawer LL, MacKay S, Copeland EM, et al. Tumour cell nitric oxide inhibits cell growth in vitro, but stimulates tumorigenesis and experimental lung metastasis in vivo. J Surg Res 1996;63:49-52. [CrossRef]

25. Farias-Eisner R, Sherman MP, Aeberhard E, Chaudhuri G. Nitric oxide is an important mediator for tumoricidal activity in vivo. Proc Natl Acad Sci USA 1994;91:9407-11. [CrossRef]
26. Hofseth LJ, Hussain SP, Wogan GN, Harris CC. Nitric oxide in cancer and chemoprevention. Free Radic Biol Med 2003;34:955-68. http://dx.doi.org/10.1016/S0891-5849(02)01363-1. [CrossRef]

27. Cui S, Reichner JS, Mateo RB, Albina JE. Activated murine macrophages induce apoptosis in tumour cells through nitric oxide-dependent or -independent mechanisms. Cancer Res 1994;54:2462-7.

28. Fukumura D, Kashiwagi S, Jain RK. The role of nitric oxide in tumour progression. Nat Rev Cancer 2006;6:521-34. [CrossRef]

29. Gotoh T, Araki M, Mori M. Chromosomal localization of the human arginase II gene and tissue distribution of its mRNA. Biochem Biophys Res Commun 1997;233:487-91. [CrossRef]

30. Bachrach U. Polyamines and cancer: minireview article. Amino Acids 2004;26:307-9. [CrossRef]

31. Gugliucci A. Polyamines as clinical laboratory tools. Clin Chim Acta 2004;344:23-35. [CrossRef]

32. Sumi S, Beauchamp RD, Townsend CM, Uchida T, Murakami M, Rajaraman S, et al. Inhibition of pancreatic adenocarcinoma cell growth by lovastatin. Gastroenterology 1992;103:982-9.

33. Poynter JN, Gruber SB, Higgins PD, Almog R, Bonner JD, Rennert HS, et al. Statins and the risk of colorectal cancer. $N$ Engl J Med 2005;352:2184-92. [CrossRef]

34. Lai SW, Liao KF, Lai HC, Muo CH, Sung FC, Chen PC. Statin use and risk of hepatocellular carcinoma. Eur J Epidemiol 2013;28:485-92. [CrossRef]

35. Seiler N. Catabolism of polyamines. Amino Acids 2004;26:217-33. [CrossRef] 